University of New Hampshire

University of New Hampshire Scholars' Repository New Hampshire Agricultural Experiment Station New Hampshire Agricultural Experiment Station
Publications

$12-1-2012$

\title{
Southern expansion of the brown alga Colpomenia peregrina Sauvageau (Scytosiphonales) in the Northwest Atlantic Ocean
}

\author{
Lindsay A. Green \\ University of New Hampshire, Durham \\ Arthur C. Mathieson \\ University of New Hampshire, Durham, Arthur.Mathieson@unh.edu \\ Christopher D. Neefus \\ University of Rhode Island, chris.neefus@unh.edu \\ Hannah M. Traggis \\ University of New Hampshire, Durham \\ Clinton J. Dawes \\ University of New Hampshire, Durham
}

Follow this and additional works at: https://scholars.unh.edu/nhaes

Comments

This is an article published by De Gruyter in Botanica Marina in 2012, available online: https://dx.doi.org/10.1515/

bot-2012-0157

\section{Recommended Citation}

Lindsay A. Green, Arthur C. Mathieson, Christopher D. Neefus, Hannah M. Traggis, Clinton J. Dawes. Southern expansion of the brown alga Colpomenia peregrina Sauvageau (Scytosiphonales) in the Northwest Atlantic Ocean. Botanica Marina 2012; 55(6): 643-647. https://dx.doi.org/10.1515/ bot-2012-0157

This Article is brought to you for free and open access by the New Hampshire Agricultural Experiment Station at University of New Hampshire Scholars' Repository. It has been accepted for inclusion in New Hampshire Agricultural Experiment Station Publications by an authorized administrator of University of New Hampshire Scholars' Repository. For more information, please contact Scholarly.Communication@unh.edu. 


\title{
Short communication
}

\author{
Lindsay A. Green*, Arthur C. Mathieson, Christopher D. Neefus, Hannah M. Traggis \\ and Clinton J. Dawes
}

\section{Southern expansion of the brown alga Colpomenia peregrina Sauvageau (Scytosiphonales) in the Northwest Atlantic Ocean}

\begin{abstract}
Blackler first recorded Colpomenia peregrina in the Northwest Atlantic based on collections from Nova Scotia, Canada. Five decades later we found large quantities of $C$. peregrina in Maine, USA, even though it was absent during earlier floristic studies in this region. Thus, C. peregrina has undergone a rapid southern expansion along the Northwest Atlantic coast. While the causes of such an expansion are unknown, it could have a major effect on both shellfish cultivation and native seaweeds within New England because of competitive interactions and increased drag.
\end{abstract}

Keywords: brown alga; Colpomenia peregrina; introduction; Northwest Atlantic Ocean.

\footnotetext{
*Corresponding author: Lindsay A. Green, Department of Biological Sciences, University of New Hampshire, Durham, NH 03824, USA, e-mail: lindsay.green@unh.edu

Arthur C. Mathieson: Department of Biological Sciences, University of New Hampshire, Durham, NH 03824, USA; and Jackson Estuarine Laboratory, University of New Hampshire, Durham, NH 03824, USA Christopher D. Neefus: Department of Biological Sciences, University of New Hampshire, Durham, NH 03824, USA

Hannah M. Traggis: Department of Biological Sciences, University of New Hampshire, Durham, NH 03824, USA

Clinton J. Dawes: Jackson Estuarine Laboratory, University of New Hampshire, Durham, NH 03824, USA; and Department of Biology, University of South Florida, Tampa, FL 33620, USA
}

The genus Colpomenia (Endlicher) Derbès et Solier is a globular, saccate brown alga found within temperate and tropical waters worldwide (Boo et al. 2011). Colpomenia peregrina Sauvageau is an epiphytic member of the Scytosiphonales that grows on a variety of hosts (Blackler 1967). It has a single plastid with one pyrenoid per cell, a heteromorphic life history alternating between an erect parenchymatous saccate gametophyte and a pseudoparenchymatous sporophytic crust, with only the gametophyte producing plurilocular gametangia (Clayton 1979, Cho et al. 2001). The gross morphological similarities between C. peregrina and Leathesia marina (Lyngbye) Decaisne may have previously caused confusion as to the presence of the former species (Blackler 1967).

Although $C$. peregrina is native to the Northwest Pacific, its type location is Brittany, France (Sauvageau 1927), where it was initially characterized during the early $20^{\text {th }}$ century (Blackler 1967, Vandermeulen and DeWreede 1986). In France, C. peregrina earned the nickname "oyster thief" and was distinguished from $C$. sinuosa after causing significant damage to the oyster industry when older attached thalli became buoyant and often displaced shellfish (Blackler 1967). Sauvageau (1927) recognized that the alga differed from $C$. sinuosa (Mertens ex Roth) Derbès et Solier by its smoother, thinner thalli and described it as a new species. Blackler (1967) reported that it spread rapidly on the east coasts of England and Scotland, as well as Holland (1921), Denmark (1939), the Mediterranean (1939), and Norway (1949); its rapid establishment and extensive spreading in Europe have been well documented.

The initial presence of $C$. peregrina in the Northwest Atlantic was documented by Blackler (1964) based on a 1960 collection by A.R.A. Taylor from Atkins Point, Nova

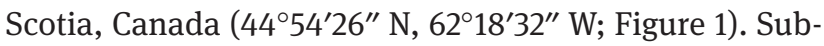
sequently, it was recorded from two southwestern Nova

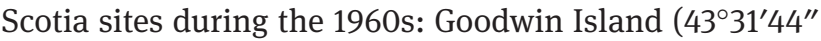
$\mathrm{N}, 65^{\circ} 47^{\prime} 05^{\prime \prime} \mathrm{W}$, collected by C. MacFarlane and G.M. Mil-

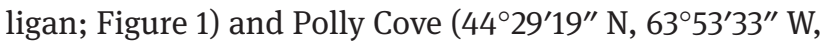
collected by D. Pace; Figure 1) followed by a fourth Nova Scotia site at Bon Portage Island $\left(43^{\circ} 28^{\prime} 0^{\prime \prime} \mathrm{N}, 65^{\circ} 41^{\prime} 60^{\prime \prime}\right.$, collected by E. Fraser, D. Smith, and K. Lynch; Figure 1). Bird and Edelstein (1978) confirmed these early records and re-designated some specimens that were improperly identified as L. marina. In the late 1970s, C. peregrina was documented from another Nova Scotia site at Hospi-

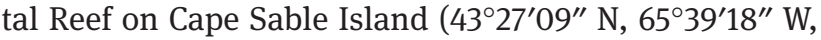




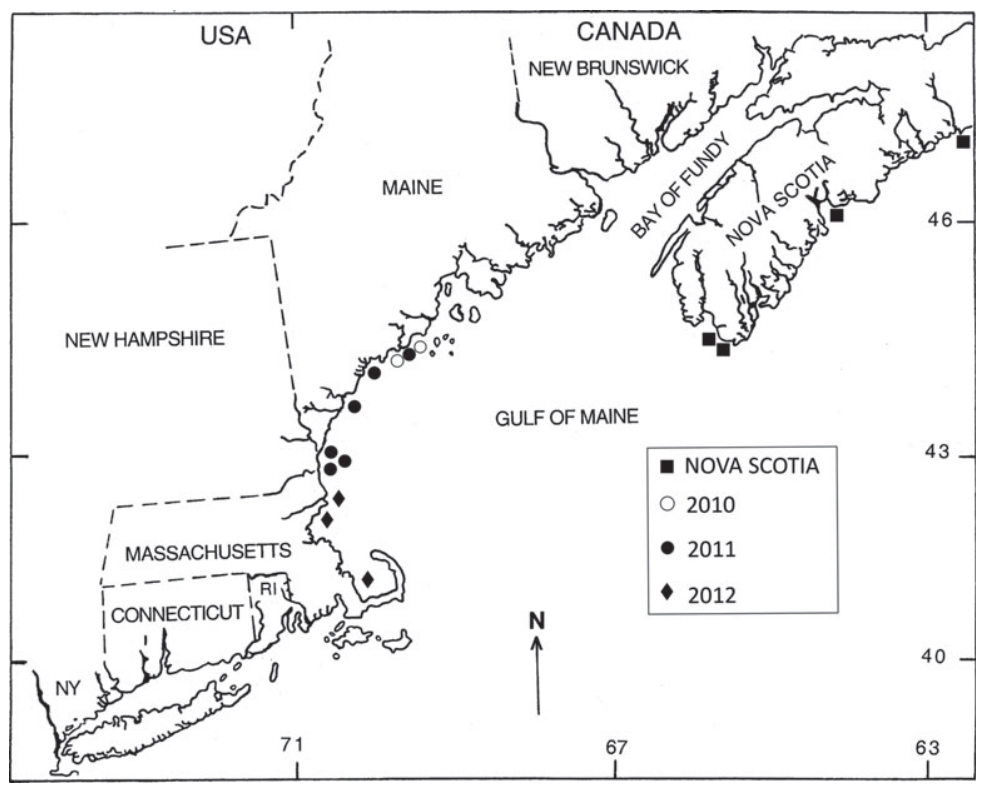

Figure 1 Colpomenia peregrina.

Map of the Gulf of Maine indicating the locations of samples collected in Nova Scotia, Canada (Grand Barachois Lagoon off Newfoundland not shown, 1960s and 1970s) as well as Maine, New Hampshire and Massachusetts collections from 2010, 2011, and 2012. Due to scale, some circles indicate more than one collection site.

collected by J.S. Wilson; Figure 1) followed by a collection in the early 1980s from Grand Barachois Lagoon $\left(46^{\circ} 48^{\prime} 20^{\prime \prime} \mathrm{N}, 5^{\circ} 14^{\prime} 26^{\prime \prime}\right.$ pers. comm., R.G. Hooper) located between Saint Pierre and Miquelon Islands, Newfoundland.

In the summer of 2011, we initially collected from extensive populations of $C$. peregrina at Fort Foster, Kittery, Maine ( $43^{\circ} 03^{\prime} 55^{\prime \prime} \mathrm{N}, 70^{\circ} 40^{\prime} 54^{\prime \prime}$ W, Figure 1). Subsequently, re-evaluation of earlier photographic records from mid-coastal Maine confirmed that it had been misidentified as L. marina during the summer of 2010 on

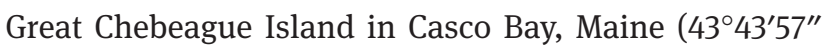
$\mathrm{N}, 70^{\circ} 07^{\prime} 26^{\prime \prime}$ W, collected by A. and D. Swafford and J.

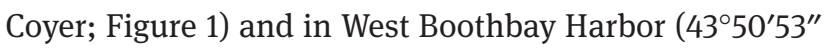
N, 69 $38^{\prime} 36^{\prime \prime}$ W, collected by P. Thayer; Figure 1). Earlier collections in the same geographic areas (Mathieson et al. 2007, 2008a,b, 2010) suggest that it was not present prior to 2007 and re-evaluations of herbarium vouchers of L. marina $(\mathrm{n}=121)$ collected from Newfoundland to Delaware during 1938-2005 confirmed the absence of $C$. peregrina. Given its rapid establishment and expansion in other geographic areas (Blackler 1964), we set out to determine the extent to which it had become established in the Gulf of Maine (i.e., Bay of Fundy to Cape Cod, Massachusetts) and to genetically verify that it was the same species previously documented in Nova Scotia (Bird and Edelstein 1978).
We collected from low intertidal and shallow subtidal zones from mid-coastal Maine to southern Massachusetts, including two offshore islands within the Isles of Shoals in New Hampshire/Maine (Figure 1). Herbarium sheet vouchers were prepared and deposited in the Albion R. Hodgdon Herbarium (NHA) at the University of New Hampshire. Biomass estimates of $C$. peregrina were made during the summer of 2011 by SCUBA diving along metered transects at three different sites: Fort Foster Kittery, Maine, Appledore Island, Maine (42 $59^{\prime} 04^{\prime \prime} \mathrm{N}, 70^{\circ} 37^{\prime} 06^{\prime \prime} \mathrm{W}$ ) and Star Island, New Hampshire ( $\left.42^{\circ} 58^{\prime} 31^{\prime \prime} \mathrm{N}, 70^{\circ} 36^{\prime} 58^{\prime \prime} \mathrm{W}\right)$. Eight randomly selected destructive quadrats $(0.25 \times 0.25 \mathrm{~m})$ were taken along a $100 \mathrm{~m}$ transect run perpendicular from the shore down through the intertidal and extending into the shallow subtidal. All biomass within each quadrat was scraped from the underlying substrata. Algal specimens were identified to species (Mathieson et al. 2008b for taxonomic references) and damp-dried weight and percent composition quantified. Measurements of thallus diameter and height were recorded for all $C$. peregrina samples ( $\mathrm{n}=528)$, as well as epiphytic host specificity.

Representative specimens from Maine (Fort Foster and Appledore Island), New Hampshire (Fort Stark, Newcastle $43^{\circ} 03^{\prime} 22^{\prime \prime} \mathrm{N}, 70^{\circ} 42^{\prime} 41^{\prime \prime} \mathrm{W}$ and Star Island), and Massachusetts (Niles Beach, Gloucester 42 $32^{\circ} 52^{\prime \prime} \mathrm{N}$, $70^{\circ} 39^{\prime} 23^{\prime \prime} \mathrm{W}$ and Sandwich, Cape Cod $41^{\circ} 46^{\prime} 28^{\prime \prime} \mathrm{N}$, 
$70^{\circ} 29^{\prime} 36^{\prime \prime}$ W), USA were used for molecular species identification and comparison (Figure 1). Material for molecular analysis was desiccated in silica gel. Four herbarium voucher specimens collected in the 1960s and 1970s from Nova Scotia, Canada (Polly Cove, Bon Portage Island, and Hospital Reef) were also analyzed. Total DNA was extracted from $2 \times 2 \mathrm{~mm}$ samples using a NucleoSpin Plant II kit (Machery-Nagel, Düren, Germany), following the manufacturer's instructions. The extracted DNA was stored at $4^{\circ} \mathrm{C}$ for use the same day or $-20^{\circ} \mathrm{C}$ for later use in amplifying the cox3 gene.

Specific primer pairs for amplification and gene sequencing were newly designed as follows. F1: ATAACTATGARGGTGGGGGWGAAT $5^{\prime}$ to $3^{\prime}$ and R1: GARCCATARACACCATCAGACATA $5^{\prime}$ to $3^{\prime}$. An Eppendorf Mastercycler (Model 533, Hamburg, Germany) was used for all PCR amplifications. A TaKaRa ExTaq reaction kit (Takara Shuzo, Shiga, Japan) was used with a total reaction volume of $50 \mu \mathrm{l}$ consisting of $5.0 \mu \mathrm{l} 10 \times$ ExTaq buffer, 5.0 $\mu \mathrm{l}$ of $25 \mathrm{~mm} \mathrm{MgCl}_{2}, 50 \mu \mathrm{M}$ dNTP mixture, $0.4 \mu \mathrm{M}$ of each primer, 1.25 U TaKaRa ExTaq, and 4.0 $\mu$ l of DNA solution (containing between 0.5 and $1.0 \mu \mathrm{g}$ DNA). PCR was performed with an initial denaturation step at $94^{\circ} \mathrm{C}$ for 4 mins, followed by 35 cycles of $30 \mathrm{~s}$ at $94^{\circ} \mathrm{C}, 30 \mathrm{~s}$ at $56^{\circ} \mathrm{C}$, and $1 \mathrm{~min}$ at $72^{\circ} \mathrm{C}$, and a final extension cycle at $72^{\circ} \mathrm{C}$ for 10 mins. The PCR products were purified using gel electrophoresis and sequenced at the HCGS DNA Sequencing Facility, University of New Hampshire.

Twenty-one cox3 sequences were used for the phylogenetic analysis: 20 previously published (Silberfeld et al. 2010, Boo et al. 2011) and one representative from the Northwest Atlantic (present study). Maximum-likelihood phylogenetic analysis was performed using MEGA 4.0 software (Tamura et al. 2007) with the Hasegawa-KishinoYano (HKY) $+\Gamma$ model. Bootstrap values were calculated using 1000 replicates.

Representative samples from Maine, New Hampshire and Massachusetts, USA plus early voucher specimens from Nova Scotia, Canada all yielded identical cox3 sequences that were not an exact match to any previously

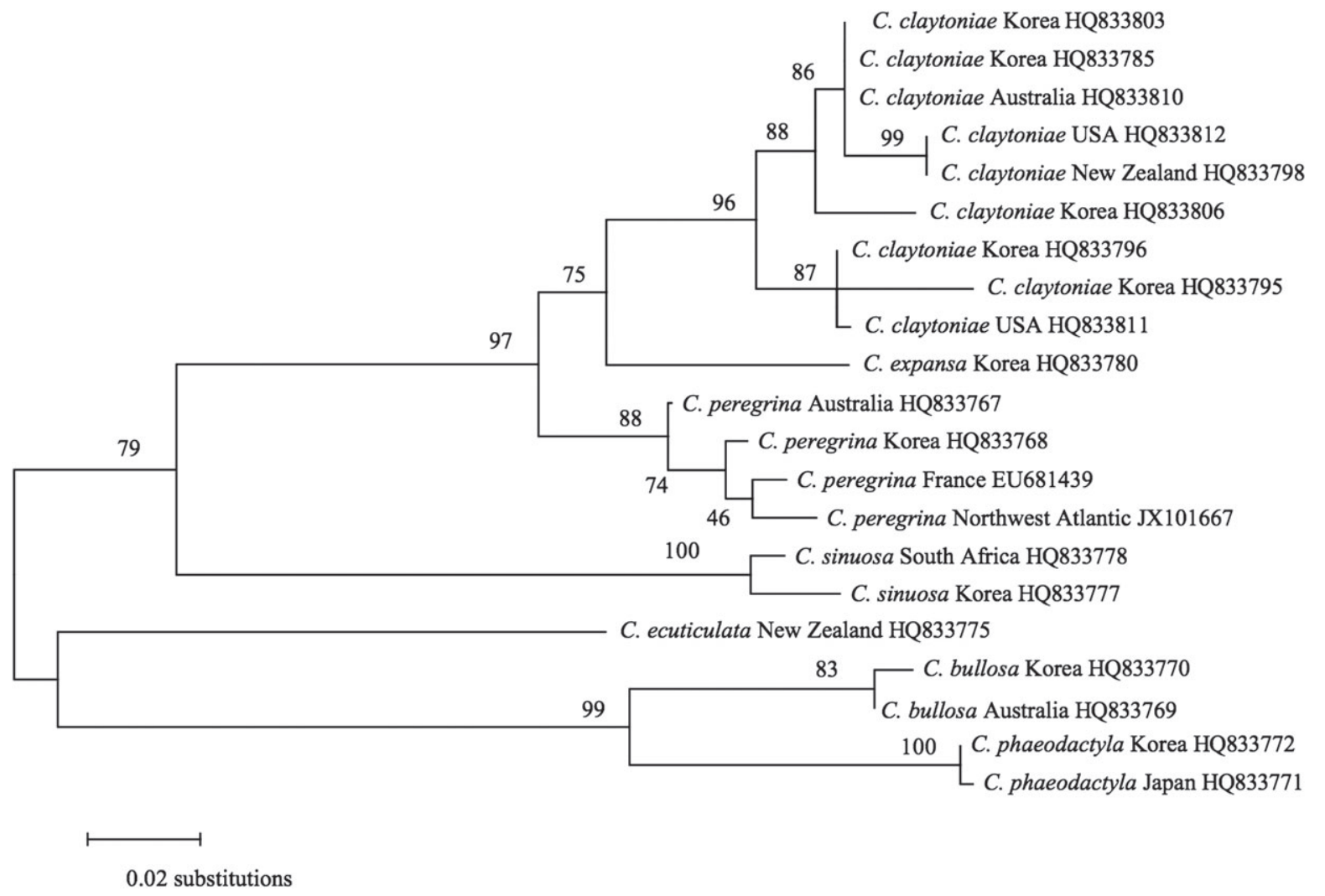

Figure 2 Colpomenia.

Maximum likelihood tree derived from the analysis of $\operatorname{cox} 3$ sequences in the genus using the $\mathrm{HKY}+\Gamma$ evolution model. The numbers above or near the branches are bootstrap values from the maximum likelihood analysis and species, country of origin, and GenBank accession numbers are listed. 
published sequence. Based on the phylogenetic analysis, our Northwest Atlantic samples fell within C. peregrina, which showed less variability than $C$. claytoniae (Figure 2). All novel sequences from this study have been submitted to GenBank (Accession numbers JX101661-JX101675).

Biomass surveys showed an abundance of $C$. peregrina within the low intertidal and shallow subtidal zones at the three study sites. Due to the nature of random sampling some quadrats lacked $C$. peregrina, resulting in a wide variation in biomass. The highest average biomass was recorded at Appledore Island $\left(50.7 \pm 31.7 \mathrm{~g} \mathrm{~m}^{-2}\right.$, mean $\left.\pm \mathrm{SE}\right)$ followed by Star Island $\left(28.3 \pm 10.0 \mathrm{~g} \mathrm{~m}^{-2}\right)$ and Fort Foster $\left(6.9 \pm 4.3 \mathrm{~g} \mathrm{~m}^{-2}\right)$. Colpomenia peregrina had a wide range of statures, with diameters ranging from 0.1 to $5.8 \mathrm{~cm}$ at Appledore Island, $0.1-9.0 \mathrm{~cm}$ at Star Island, and $0.1-7.0 \mathrm{~cm}$ at Fort Foster. Similarly, heights ranged from 0.1 to 4.8, 0.1 to 3.7 , and 0.1 to $4.0 \mathrm{~cm}$ at Appledore Island, Star Island, and Fort Foster, respectively.

At Appledore Island, C. peregrina occurred on Chaetomorpha picquotiana Montagne ex Kützing, Corallina officinalis L., Cystoclonium purpureum (Hudson) Batters, Mastocarpus stellatus (Stackhouse) Guiry, and Neosiphonia harveyii (J.W. Bailey) M.-S. Kim, H.-G. Choi, Guiry et G.W. Saunders, with $C$. officinalis being the major host $(89.5 \%, \mathrm{n}=251)$. At Star Island it occurred on Ascophyllum nodosum (L.) Le Jolis, Chaetomorpha ligustica (Kützing) Kützing, Cladophora sericea (Hudson) Kützing, Cladostephus spongiosus (Hudson) C. Agardh, Coccotylus truncata (Pallas) M.J. Wynne and J.N. Heine, C. purpureum, Fucus vesiculosus L., Mastocarpus stellatus, Polysiphonia fucoides (Hudson) Greville, and Rhodomela cerfervoides (Hudson) P.C. Silva, with Fucus vesiculosus being the dominant host $(50.0 \% ; \mathrm{n}=228)$. At Fort Foster it occurred on $C$. picquotiana, Chondrus crispus Stackhouse, C. officinalis, and Zostera marina L., with $C$. officinalis again the major host (65.4\%; $\mathrm{n}=49)$.

During the summer and fall of 2011, extensive populations of $C$. peregrina were recorded at 11 sites in midcoastal to southern Maine, while it was also collected as far south as Cape Cod, Massachusetts during the spring of 2012 (Figure 1). Genetic analysis confirmed the identification of $C$. peregrina using representative samples from Maine to Massachusetts, with each being identical to original voucher specimens from Nova Scotia (Figure 2). Biomass surveys indicate the species is highly abundant (6.9-50.7 $\mathrm{g} \mathrm{m}^{-2}$ ), morphologically variable, and grows on a wide range of hosts.

In the Northwest Pacific, fertile plants of $C$. peregrina can be seen year round. High temperatures and low salinities during the summer as well as low temperatures during winter can limit its growth (Vandermeulen and DeWreede 1986). We initially assumed that C. peregrina was a spring-summer annual; however, extensive monthly collections at Fort Foster have shown that it is present year round, particularly within the shallow subtidal zone. Our biomass estimates are slightly higher than previously recorded by Vandermeulen and DeWreede (1986) from the Northeast Pacific. They suggested that the saccate form of $C$. peregrina was opportunistic, even though both its photosynthetic rates and grazing by herbivores were low. Our observations are consistent with the occurrence of low herbivory rates, as no holes or cuts were observed.

Introduced species can cause major problems by altering natural communities and causing economic losses (Mathieson et al. 2007, 2008a,b). Currently there are approximately 120 introduced seaweed taxa known worldwide (Nyberg and Wallentinus 2005), and about 25 within the Northwest Atlantic (Mathieson et al. 2007, 2008a,b, Hofmann et al. 2010, Schneider 2010). The introduction of $C$. peregrina to France caused significant economic losses to the oyster industry (Blackler 1967). Although no deleterious impacts of $C$. peregrina on the New England shellfish industry have been reported, it has the potential to become a major pest considering its rapid expansion during the past 2 years. In New England, the eastern oyster industry was valued at US \$117.6 million in 2010 (pers. comm., National Marine Fisheries Service). Since $C$. peregrina is an epiphyte on several native seaweeds within the low intertidal and shallow subtidal zones, it may also impact hosts by increasing drag and competing for space and limited resources.

Acknowledgments: We acknowledge the help of Marian Munro, curator of Botany at the Nova Scotia Natural History Museum for lending us herbarium specimens of $C$. peregrina. Ann Swafford, David Swafford, and James Coyer are thanked for reporting the possible occurrence of $C$. peregrina from Great Chebeague Island, while Peter Thayer and Lauren Stockwell both forwarded photographs from Boothbay Harbor and Allen Island, respectively. This work was supported by the NH Sea Grant College Program (Project Number R/CFR-14). Partial funding was provided by the New Hampshire Agriculture Experiment Station (NHAES; Project 11H545). This is Scientific Contribution Number 2448 from the NHAES, as well as contribution Number 511 from UNH's Jackson Estuarine Laboratory and Center for Marine Biology.

Received May 16, 2012; accepted August 15, 2012; online first September 10, 2012 


\section{References}

Bird, C.J. and T. Edelstein. 1978. Investigations of the marine algae of Nova Scotia XIV: Colpomenia peregrina Sauv. (Phaeophyta: Scytosiphonaceae). Proc. N.S. Inst. Sci. 28: 181-187.

Blackler, H. 1964. Some observations on the genus Colpomenia (Endlicher) Derbès et Solier. Proc. Int. Seaweed Symp. 4: 50-54.

Blackler, H. 1967. The occurrence of Colpomenia peregrina (Sauv.) Hamel in the Mediterranean (Phaeophyta, Scytosiphonales). Blumea 15: 5-8.

Boo, S.M., K.M. Lee, G.Y. Cho and W. Nelson. 2011. Colpomenia claytonii sp. nov. (Scytosiphonaceae, Phaeophyceae) based on morphology and mitochondrial cox3 sequences. Bot. Mar. 54: 159-167.

Cho, G.Y., H.S. Yoon, H-G. Choi, K. Kogame and S.M. Boo. 2001. Phylogeny of the family Scytosiphonaceae (Phaeophyta) from Korea based on sequences of plastid-encoded RuBiCo spacer region. Algae 16: 145-150.

Clayton, M.N. 1979. The life history and sexual reproduction of Colpomenia peregrina (Scytosiphonaceae, Phaeophyta) in Australia. Br. Phycol. J. 14: 1-10.

Hofmann, L., J.C. Nettleton, C.D. Neefus and A.C. Mathieson. 2010. Cryptic diversity of Ulva (Ulvales, Chlorophyta) in the Great Bay Estuarine System (Atlantic USA): Introduced and indigenous distromatic species. Eur. J. Phycol. 45: 230-239.

Mathieson, A.C., J. Pederson, C.D. Neefus, C.J. Dawes and T.L. Bray. 2007. Multiple assessments of introduced seaweeds in the Northwest Atlantic. J. Mar. Sci. 65: 730-741.
Mathieson, A.C., E.J. Hehre, C. J. Dawes and C.D. Neefus. 2008a. An historical comparison of seaweed populations from Casco Bay, Maine. Rhodora 110: 1-102.

Mathieson, A.C., J. Pederson and C.J. Dawes. 2008b. Rapid assessment surveys of fouling and introduced seaweeds in the North Atlantic. Rhodora 110: 406-478.

Mathieson, A.C., C.J. Dawes, E.J. Hehre and L.G. Harris. 2010. Floristic studies of seaweeds from Cobscook Bay, Maine. Northeast. Nat. 16: 1-48.

Nyberg, C.D. and I. Wallentinus. 2005. Can species be used to predict marine macroalgal introductions? Biol. Invasions 7: 265-279.

Sauvageau, C. 1927. Sur le Colpomenia sinuosa Derb. et Sol. Bull. Stn. Biol. Arachon 24: 309-350.

Schneider, C.W. 2010. Report on a new invasive alga in the Atlantic United States "Heterosiphonia" japonica in Rhode Island. J. Phycol. 46: 653-657.

Silberfeld, T., J.W. Leigh, H. Verbruggen, C. Cruaud, B. de Reviers and F. Rosseau. 2010. A multi-locus time-calibrated phylogeny of the brown algae (Heterokonta, Ochrophyta, Phaeophyceae): investigating the evolutionary nature of the "brown algal crown radiation”. Mol. Phylogenet. Evol. 56: 659-674.

Tamura, K., J. Dudley, M. Nei and S. Kumar. 2007. Mega4: Molecular Evolutionary Genetics Analysis (MEGA) software version 4.0. Mol. Biol. Evol. 24: 1596-1599.

Vandermeulen, H. and R.E. DeWreede. 1986. The phenology, mortality, dispersal and canopy species interaction of Colpomenia peregrina (Sauv.) Hamel in British Columbia. J. Exp. Mar. Biol. Ecol. 99: 31-47. 
Copyright of Botanica Marina is the property of De Gruyter and its content may not be copied or emailed to multiple sites or posted to a listserv without the copyright holder's express written permission. However, users may print, download, or email articles for individual use. 